\title{
The Effect of Top Management Commitment on Firm Performance through the Green Purchasing and Supplier Relationship Management in 3-Star Hotel Industry in Surabaya
}

\author{
Novia Chandra Tanuwijaya ${ }^{1}$, Zeplin Jiwa Husada Tarigan ${ }^{2}$, Hotlan Siagian ${ }^{3 *}$ \\ ${ }^{1,2,3}$ Faculty of Business and Economics, Petra Christian University \\ Jl. Siwalankerto 121-131, Surabaya 60236, Indonesia \\ *Corresponding author: hotlan.siagian@petra.ac.id
}

\begin{abstract}
The local government needs to facilitate the Hotel through industry regulations, and one of the requirements is the obligation of each Hotel to pay attention to environmentally friendly practices. This study investigates the effect of top management commitment on firm performance through green purchasing and supplier relationship management in the 3-star Hotel. This study used a Census survey for all 71 3-star Hotel domiciled in the City of Surabaya. Data collection used a questionnaire with a five-point Likert scale. Questionnaire distribution was conducted by email, social media, and direct delivery to the respondent. Sixty-one from seventy-one questionnaires, a response rate of $86 \%$, were filled in duly and considered valid for further analysis. Data analysis used the partial least square technique by utilizing Smart PLS. The result of the analysis demonstrated that top management commitment affects supplier relationship management by path coefficient of 0.544 Top management commitment affects firm performance with path coefficient of 0.281 . However, this study indicated that top management commitment does not affect green purchasing. Furthermore, supplier relationship management has a significant effect on green purchasing with path coefficient of 0.391 . Similarly, supplier relationship management also affects firm performance with a path coefficient of 0.377 . Finally, Green purchasing significantly improves firm performance with a path coefficient of 0.226 . This work provides a new insight for the manager on how to increase firm performance in the context of supply chain management. This study could contribute to enriching the current research in supply chain management.
\end{abstract}

Keywords: Top Management Commitment; Green Purchasing; Supplier Relationship; Firm Performance.

\section{Introduction}

The tourism sector is projected to become a "core economy" and the most significant contributor of foreign exchange in Indonesia for the next five years. This projection is based on the growth of Indonesia's tourism competitiveness. Consequently, the increase in the quantity and quality of existing facilities should follow the tourist's growth trend. One of the primary concerns is the issue of global warming. The tourism sector is an essential part of helping to create a green and friendly environment for hotels. Many efforts were made to minimize the occurrence of global warming through steps implemented through the movement for green hoteliers to commit to implementing environmentally-friendly principles. This 3 -star Hotel is increasingly in demand because it is suitable for people who want to gain experience inferior to 5star hotels. Still, with affordable prices and good service for consumers, it is not uncommon for 3 star hotels to be increasingly in demand by consumers (Junita, 2016; Teguh et al., 2020).
The Hotel provides services to its customers by meeting the various daily needs of its customers, such as food, laundry, and toiletries. This demand makes the hotel activities produce miscellaneous liquid waste and garbage, such as household waste. Therefore, the hospitality industry is considered a significant contributor to environmental pollution. Many hotel industries also desire to implement environmentally friendly practices, especially ecological awareness, which is no longer a mandatory business requirement. In fact, instead of being an expensive inconvenience, environmental initiatives have become a competitive source. Customer and Government pressure to implement green products and their distribution forcing companies to adopt environmentally friendly practices. This pressure makes companies increasingly concerned about the environment by implementing green purchasing (Meehan and Bryde, 2011).

Green supply chain management is product management with full integration throughout its life cycle, which involves several main activities 
such as purchasing, production, material management, distribution, marketing, and reverse logistics (Giovanni and Vinzi, 2012). Green supply chain management also focuses on how organizations control the process, technology, and the ability of their suppliers to increase competitive advantage. In green supply chain management, the first step taken in organizations' implementtation is to adopt practices in green purchasing (Ali et al., 2013). The performance of green innovation is proved by adopting environment protection management such as certified against ISO 14000 . The purchasing department can use its strategic function as a strong agent of change to increase the impact on the natural environment. The involvement of suppliers in realizing green innovation is crucial because they supply the raw material or components required in developing a new product. The role of purchasing has become an essential element in increasing profits and the future survival of an organization. Top management commitment cannot impact implementing a purchasing strategy by adopting green purchasing properly in manufacturing companies (Sundarakani et al., 2010). Green purchasing can produce higher profitability, thereby encouraging improved firm performance. Green purchases have a positive and significant relationship with operational, economic, and social performance (Zailani et al., 2012). Green supply chain management activities consist of green purchasing, green processes, green marketing, green distribution, and green products, impacting firm performance (Chan et al., 2012).

The supplier is one of the representatives of the fundamental pillars to improve competitive performance [4]. In achieving the goals of green purchasing, it is necessary to integrate the process between suppliers and companies. Relationship with suppliers enables companies to interact better with suppliers. The supplier relationship management process is one of the critical concepts of supply chain management, with integration between producers and first upstream suppliers to improve product quality, performance and reduce costs to achieve higher competitive advantages (Tarigan et al., 2020). Top management commitment can be a strategic driver in implementing practices Green on the supplier (Menguc et al., 2010). In its implementation, top management commitment plays a vital role in allocating resources, building capabilities, and helping companies gain a competitive advantage. Top management's high participation in an environmental management system can be an excellent measure to demonstrate organizational commitment to the environment. The role of top management in carrying out the commitment to the organization to realize the goals and objectives of the company influences firm performance (Yusliza et al., 2019). Green operations related to green operations in hotels impact hotel performance (Siagian et al., 2019). The challenge for 3 -star hotels that want to implement green purchasing requires higher costs while main-taining their prices to be competitive does not make 3 -star hotels reluctant to implement green purchasing, especially chain hotels. This study is expected to fill the gap and enrich the current research on the issue of green concept in the Hotel industry. This study also addresses and fills the practical gap whether green purchasing contributes to the hotel performance since it is still pro and contra in adopting the green concept by the Hotel Industry or the related supplier. Therefore, this study has three objectives: first, to test the magnitude of the influence of top management commitment on supplier relation-ship management, green purchasing, and company performance. Second, to examine the effect of supplier relationship management on green purchasing and company performance, and finally, to investigate the impact of green purchasing on company performance.

\section{Literature Review}

The supply chain includes activities related to the transformation and flow of goods or services from the source of materials to end consumers, including the integration of these activities internal and external to the company (Jiputra et al., 2020). Supply chain management is used to optimize supply chain values by maximizing the flow of goods, information, and money in the supply chain, so products that reach consumers can provide satisfaction in terms of timeliness, delivery, quality of goods, and prices (Amoako et al., 2018).

\subsection{Top Management Commitment}

Top management is the people who make policies and regulations in the organization and have the highest position. The task of top management is developed from the organization's mission, goals, strategies, and business processes. Top management needs commitment and personal involvement to create and use values and quality objectives that are clear and consistent with the company's goals in developing and using welldefined systems, methods, and performance 
measures to achieve these goals (Tarigan et al., 2020). Top management commitment itself is the extent of senior-level managerial commitment, support, and leadership in preserving the company's environment and applying corporate environmental practices (Teguh et al., 2020). Top management in organizations maintains leadership responsibilities for the quality management system, with the involvement of all organizational staff. This responsibility includes ensuring the availability of resources for all staff in achieving service improvement to realize the organization's vision and mission. The indicators used to promote affective research commitment are related to top management's emotional relationship with the company. Commitment to continuity from top management is shown by the strong desire to continue to be involved in the company's improvement projects. The normative commitment of top management is demonstrated by a feeling of engagement to remain in the organization. This research adopted the top management commitment definition from study of Tarigan et al. (2020). The top management commitment is assessed using six indicators, namely, 1) Top management provides develop-ment training for its employees $\left.\left(\mathrm{X}_{1.1}\right), 2\right)$ Top management is actively involved in developing projects $\left.\left(\mathrm{X}_{1.2}\right), 3\right)$ Top management sets policies $\left.\left(\mathrm{X}_{1.3}\right), 4\right)$ Top management communicates strategy planning effectively $\left.\left(\mathrm{X}_{1.4}\right), 5\right)$ Top management provides resources according to needs $\left(\mathrm{X}_{1.5}\right)$, and 6) Top management involves the role of the supplier is carrying out the hotel strategy $\left(\mathrm{X}_{1.6}\right)$.

\subsection{Supplier Relationship Management}

Supplier relationship management is an activity carried out by the company after the supplier selection decision to maintain and develop relationships in the supplier network to get the best benefits and performance in the long run. Supplier relationship management represents relationship management that aims at the buyer and supplier to ensure, at the very least, the supplies needed with the right quality and quantity are obtained at the right time. Other aspects of supplier relationship management include involvement in product design, material selection, innovation, information sharing, technology investment, and long-term cooperation arrangements. This study defines supplier relationship management as joint investment, forming longterm contracts, and sharing information between buyer companies and suppliers (Amoako et al.,
2018). This study used eight indicators to measure supplier relationship management, namely, 1) Suppliers have good credibility in meeting needs $\left.\left(X_{2.1}\right), 2\right)$ Share solutions to the problems faced $\left.\left(\mathrm{X}_{2.2}\right), 3\right)$ Share new ideas $\left.\left(\mathrm{X}_{2.3}\right), 4\right)$ Face risks together $\left.\left(\mathrm{X}_{2.4}\right), 5\right) \mathrm{We}$ are satisfied with the cooperation with suppliers that have been ongoing $\left.\left(X_{2.5}\right), 6\right)$ Work together to achieve each other's interests $\left.\left(\mathrm{X}_{2.6}\right), 7\right)$ Commit to maintaining a longterm relationship with the supplier $\left(\mathrm{X}_{2.7}\right)$, and 8$)$ Communicate effectively $\left(\mathrm{X}_{2.8}\right)$.

\subsection{Green Purchasing}

The adoption of green supply chain management can refer to various activities and initiatives carried out by an organization to reduce its impact on the natural environment. Green supply chain management is defined as the strategic, transparent, integration, and achievement of organizational social, environmental, and econo-mic goals in the systemic coordination of key business processes between organizations to improve the long-term performance and supply chain partners (Laosirihongthong et al., 2013). Green supply chain management is defined as a method for integrating environmental thinking into supply chain management, along with product design, material sourcing and selection, manufacturing processes, delivery of the final product to consumers, and the final management of the life of the merchandise after its useful life. Green supply chain management is a method that converts inputs into outputs by reducing harmful substances, increasing the potential in lighting, and minimizing waste by actively planning and redesigning green processes (Sundarakani et al., 2010). Green supply chain management (GSCM) practices minimize waste and preserve the living standard of products and natural resources (Diabet et al., 2013). Green supply chain management integrates all organizations involved in the supply chain to consider the green issue. One green supply chain management partner is the supplier, which supplies the raw material or components required for production. Green purchasing on environmental aspects is considered along with other dimensions such as quality, cost, delivery, technology, services, and other strategic variables of interest when making purchasing decisions. This study addresses the issue of green purchasing as one of the research variables. The concern is to examine how green purchasing contributes to firm performance in the manufacturing industry. Green purchasing is measured using four measurement 
items: waste control, compliance to regulations, vendor selection, material selection, and outsourcing. This study adopted research by Kiarie et al, (2016) and Ndua et al. (2018) in measuring the green purchasing using three indicators, namely, 1) Minimize waste through the purchase of products that are easily recycled $\left(\mathrm{Z}_{1}\right), 2$ ) Adherence to environmental regulations in product procurement $\left(\mathrm{Z}_{2}\right), 3$ ) Selecting a supplier with environmentally friendly criteria $\left.\left(Z_{3}\right), 4\right)$ Collaborate with suppliers in improving environmentally friendly performance $\left(Z_{4}\right)$, and 5) Buying products labeled eco-label $\left(\mathrm{Z}_{5}\right)$.

\subsection{Firm Performance}

Performance is a function of two variables, efficiency and effectiveness. Firm performance is defined as how the company achieves its market goals and overall objectives. The firm's performance is the actual results or output produced by a company, measured and compared with the expected output (Jahanshahi et al., 2012). A clear definition of firm performance is needed in clarifying the multidimensional relationship between SCI and firm performance. Existing supply chain integration is increasingly focused on testing the benefits of supply chain integration (SCI) associated with operations and business together (Tarigan et al., 2019; Jiputra et al., 2020). Operational performance and business performance are two measures of firm performance. Specifically, operational performance refers to an increase in a company's response to a changing environment relative to its competitors (Laosirihongthong et al., 2013). In contrast, business performance refers to financial performance related to return on investment, profitability, and net profit. However, both measurements are interrelated since they indicate the achievement of a company operating in a period, commonly in one year. The firm performance itself is the actual results or output produced by a company, measured and compared with the expected results or output (Diabet et al., 2013); (Jahanshahi et al., 2012). Managerial environmental interests influence how green innovation practices impact performance strong and competitive advantage (Ar. I. M., 2012). Green purchasing has a positive and significant impact on firm performance in the context of company internal management and supplier selection, which ultimately leads to the company's reputetion (Siagian et al., 2019). Today, the issue of a green environment is becoming a central issue since the observed climate change has indicated a worrying level. The integration of the SRM process is a collective performance of activities that refer to the acquisition, flow, and storage related to materials to reduce costs and improve performance Smith and Rupp (2013). The improved performance and competitive advantage can be achieved with supplier relationship management, which includes trust, supporting suppliers to improve their processes, sharing information, supplier involvement in developing new products, and long-term relationships (AlAbdallah et al., 2014). The indicators of research measure firm performance in terms of environmental performance, economic performance, and operational performance (Perotti et al., 2012). This study assesses the firm performance using seven indicators from Perotti et al. (2012), namely, 1) Minimizes waste $\left.\left(Y_{1}\right), 2\right)$ Has a growing market share $\left.\left(\mathrm{Y}_{2}\right), 3\right)$ Saves on expenses $\left.\left(\mathrm{Y}_{3}\right), 4\right)$ Reduces energy consumption $\left.\left(\mathrm{Y}_{4}\right), 5\right)$ Implements green hotels $\left.\left(\mathrm{Y}_{5}\right), 6\right)$ Provides services efficiently ( $\left.\mathrm{Y}_{6}\right)$, and 7 ) On time in meeting customer demand $\left(\mathrm{Y}_{7}\right)$.

\subsection{Hypothesis Development}

a. The relationship between top management commitment, supplier relationship management, green purchasing, and firm performance

Researchers have emphasized that top management commitment and supplier relationships are influenced by process integration (Goyal et al., 2018). The study found that top management commitments also positively and significantly impact environmental collaboration with suppliers and showed that top management, which leads environmental cooperation proactively and performs a vertical integration with suppliers, enhances green purchasing adoption (Yen \& Yen, 2012). Moreover, study by Kezia et al. (2021) also suggested that transformational leadership could enhance the firm perfor-mance. The above description postulates a hypothesis:

H1: Top management commitment affect supplier relationship management.

Top management commitments and supplier relationships have significant positive associations with environmental green purchasing practices (Abdullah et al., 2018). Furthermore, top management commitment was an essential driver of green purchasing 
(Blome et al., 2014). Yen and Yen (2012) examine internal motives that influence companies' adoption of green purchasing, such as top management commitments and partnerships with suppliers and external motives that include regulatory and customer pressures. Hence, the following hypothesis is proposed:

H2: Top management commitment affects green purchasing.

Top management commitment to mission statements modulates mission impact on firm performance through communication, company wide engagement, setting targets, and revisions on time (Morrell et al., 2014). Top management commitment has a significant relationship with the performance of new products (Mokhtar \& Yusof, 2010). Anne et al. (2016) shows a significant relationship between top management and performance. A study by Siagian et al. (2020) indicated that affective leadership affects business performance. In addition, a study by Semuel et al. (2017) also suggested that leadership positively improve the firm performance in the manufacturing industry in Indonesia. Besides, affective leadership practices in a manufacturing company contribute to improving the organizational performance (Tarigan et al., 2021). Moreover, a study by Jade et al. (2021) suggested that transformational leadership could enhance the firm performance in manufacturing industry. This study was conducted on the manufacturing industry in East Java, Indonesia. Therefore, the hypothesis is formulated as follows:

H3: Top management affect firm performance.

b. The relationship of supplier relationship management, green purchasing, and firm performance

According to Mentzer et al. (2012), supplier relationship management is defined as a comprehensive approach to managing a company's interaction with the organization that supplies the goods and services it uses. In addition, green purchasing practices assist companies in making decisions about suppliers and working together to provide materials, equipment, parts, and services to achieve environmental goals. Finally, green purchasing is defined as selecting affirmative and acquiring products and services that most effectively minimize negative environmental impacts during their life cycle in manufacturing, transportation, use, and recycling or disposal (Ali et al., 2013). Goh et al. (2010) argue that technology, innovation, transparency, and supplier relationship improvement are key factors when managing a green supply chain. However, many factors to consider when managing green supply chain management. Contact with suppliers is the essential factor for GSCM. A survey on 135 manufacturing companies domiciled in the region of East Java, Indonesia, revealed that a strategic partnership with a supplier enhanced the firm performance (Tarigan \& Siagian, 2021). By creating environmental requirements to purchase goods with suppliers to meet the environmental quality conditions requested by customers and stakeholders. This event can occur due to a company's environmental practices by selecting suppliers based on green purchasing requirements only to buy materials with green characteristics. Therefore, supplier relationship management can improve the environmentally friendly performance of the company itself and all suppliers and other supply chain participants.

H4: Supplier relationship management affects green purchasing.

Supply management is a general concept for all activities carried out by companies to maintain, control, and develop their base supplier. Supplier relationship management is a process that defines how a company interacts with its suppliers and is a reflection of CRM. Just as companies need to develop relationships with their customers, companies also need to build relationships with their suppliers. The desired outcome is a mutually beneficial relationship where both parties benefit. The company's ability to build supplier relationships through long-term relationships by forming collaborations with suppliers requires high commitment for both parties. Supplier relationships that are built with interactions and roles built together and formally can provide a level of long-term relationships. The Supplier relationship is realized by trusting each other, supporting suppliers to improve their processes, sharing information, supplier involvement in new product development, and long-term relationships in Abdallah et al. (2014). As Flynn et al. (2010) state, significant benefits can be gained through good relationships with suppliers, improving firm perfor- 
mance. Information sharing promotes effective management of supplier relationships between sellers and buyers and impacts performance within the organization (Lambert et al., 1998). Chrysostom and Monari (2018) stated that a positive relationship between supplier relationship management and firm performance must be recognized (Gitau \& Kosgei, 2016). Supplier relationship mana-gement argues that supplier relationship management significantly impacts the ability and firm performance (Tseng, 2014). Based on this argument, the hypothesis is proposed.

H5: Supplier relationship management affects firm performance.

\section{c. The relationship of green purchasing and firm performance}

Green purchasing involves procurement functions through various supply chain activities, such as LCA (lifecycle analysis) and typical $3 \mathrm{R}$ reduction, reuse, and recycling, part of the product and the design process. Green purchasing is the most influential driving force for businesses to promote environmentally conscious products and services. Firm performance is defined as a company's effectiveness that includes operational and financial results (Selvam et al., 2016). Green purchasing practices can help organizations increase efficiency, reduce liabilities and gain a competitive advantage. The fact is that green purchasing programs are the best way to find products with high-performance ratios and better usage rates-Green SCM as a strategic capability that improves firm performance (Fahimnia et al., 2015). Previous studies have shown that the direct effect between GSCM and improved performance is significant (Sarkis, 2012). Researchers have emphasized that top management commitment and supplier relationships are the most critical integration process constructs affecting organizational performance.

H6: Green purchasing affect firm performance

The research framework and the relationship between constructs are depicted in Figure 1.

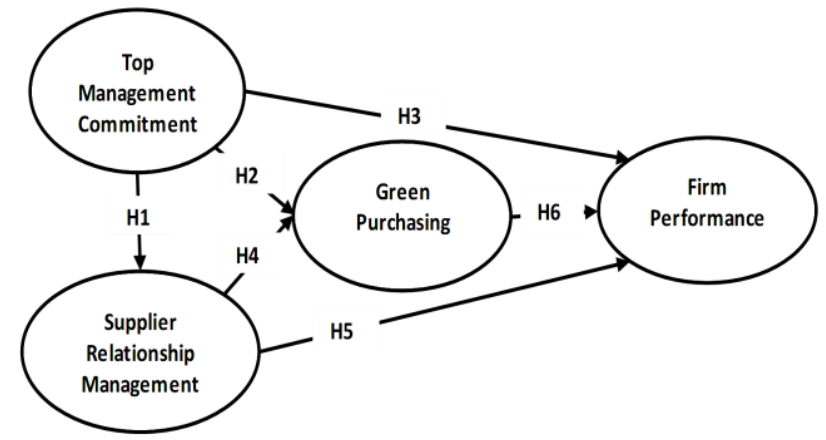

Figure 1. Research Framework and Constructs Relationship

\section{Methods}

The population of this study is a 3-star hotel in Surabaya as many as 71 . Data is collected by distributing 71 questionnaires to the purchasing division manager of all the Hotel population (Census survey). Questionnaires were distributed by submitting in the form of softcopy (by email) and hard copies of questionnaires (by hand carry) to the manager of the purchasing division of each Hotel. The questionnaire is designed using a fivepoint Likert scale starting from 1 strongly disagree to 5 strongly agree. The questionnaire is also designed to capture the respondent criteria in terms of work experiences, the length of time adopting green purchasing. This study used quantitative research methods based on the philosophy of positivism used to examine populations or specific samples (Sekaran et al., 2016). The sampling techniques used purposive sampling and data collection using a questionnaire. Data analysis used structural equation modeling (SEM) utilizing the partial least square (PLS) technique. Data analysis examines the measurement and inner model using smartPLS software version 3.0.

This study collected data from the respondent using the questionnaire designed with a five-point Likert scale with 1: strongly disagree up to 5: strongly agree. The respondents' predetermined criteria are those in the position of decision-maker from supervisor up to director in the Hotel. The purpose of the test is to examine the effect of the independent variable, namely top management commitment, on firm performance through supplier relationship management and green pur- 
chasing. The indicators of each variable have been defined previously in the literature review section. There are 26 indicators composed of 6 items for assessing the top management commitment, eight items for supplier relationship management, five items for green purchasing, and seven items for firm performance. Those items of measurement have been tailored to the Hotel industry relevancy.

\section{Results}

The first step is to perform descriptive analysis to observe the respondent's profile and assessment of the measurement model. There are sixty-one from seventy-one questionnaires (response rate 86\%) received and adequately filled in. The results in Table 1 show that the respondent of this study has working experience mostly between $1-5$ years $(90.16 \%)$ which mean that they are eligible as respondent and has enough working experience and understanding in their company operation particularly on the purchasing function. The finding also showed that most 3-star hotels in Surabaya have been practicing green purchasing for 1-3 years, with a percentage of $70.49 \%$.

Table 1. Respondent Profile

\begin{tabular}{|c|c|c|}
\hline Working Experience & Frequency & Percentage \\
\hline$<1$ year & 2 & $3.28 \%$ \\
\hline $1-5$ years & 55 & $90.16 \%$ \\
\hline $6-10$ years & 3 & $4.92 \%$ \\
\hline$>10$ years & 1 & $1.64 \%$ \\
\hline Total & 61 & $100.00 \%$ \\
\hline $\begin{array}{l}\text { Practicing Green } \\
\text { Purchasing }\end{array}$ & Frequency & Percentage \\
\hline$<1$ year & 0 & $0.00 \%$ \\
\hline $1-3$ years & 43 & $70.49 \%$ \\
\hline 4-6 years & 17 & $27.87 \%$ \\
\hline$>6$ years & 1 & $1.64 \%$ \\
\hline Total & 61 & $100.00 \%$ \\
\hline
\end{tabular}

Further analysis examines the validity and reliability of the indicators and then follows the hypothesis testing through the assessment against the path coefficient, value of t-statistics, and pvalue. An indicator is said to meet convergent validity if it has a factor loading value $>0.50$ (minimum recommended value). Table 2 demonstrated convergent and discriminant validity altogether. The value in bold shows the convergent validity existed since all values exceed 0.50 . Furthermore, the discriminant validity is shown by the fact that the value cross-loading of each indicator with other variables is less than the indicator's factor loading. The results show that the factor loading of an indicator with its corres- ponding construct (written in bold) is greater than its cross-loading with other constructs. For instance, the factor loading of $\mathrm{X}_{1.1}(0.716)$ is greater than the cross loading of of $\mathrm{X}_{1.1}$ with other constructs, namely, 0.517, 0.371, and 0.507. Hence, the discriminant validity of all indicators also existed. Table 2 also demonstrated those indicators' descriptive analysis results (mean value of the item score). All indicators have an item score mean value above 4.00 except $\mathrm{Y}_{4}$ with a score value of 3.840. This finding indicated that the companies, on average, have highly practiced the construct in their operational activities.

Table 2. Validity and Mean Value

\begin{tabular}{|c|c|c|c|c|c|}
\hline $\begin{array}{l}\text { Measure- } \\
\text { ment Item }\end{array}$ & $\begin{array}{l}\text { Item } \\
\text { Mean }\end{array}$ & TMC & SRM & GPR & FPR \\
\hline \multicolumn{6}{|c|}{ Top Management Commitment (TMC) } \\
\hline $\mathrm{X}_{1.1}$ & 4.340 & 0.716 & 0.517 & 0.371 & 0.507 \\
\hline $\mathrm{X}_{1.2}$ & 4.340 & 0.711 & 0.328 & 0.348 & 0.330 \\
\hline $\mathrm{X}_{1.3}$ & 4.340 & 0.861 & 0.394 & 0.359 & 0.555 \\
\hline $\mathrm{X}_{1.4}$ & 4.341 & 0.739 & 0.404 & 0.251 & 0.406 \\
\hline $\mathrm{X}_{1.5}$ & 4.130 & 0.671 & 0.359 & 0.282 & 0.369 \\
\hline $\mathrm{X}_{1.6}$ & 4.200 & 0.643 & 0.331 & 0.459 & 0.369 \\
\hline \multicolumn{6}{|c|}{ Supplier Relationship Management (SRM) } \\
\hline $\mathrm{X}_{2.1}$ & 4.110 & 0.293 & 0.578 & 0.312 & 0.277 \\
\hline $\mathrm{X}_{2.2}$ & 4.130 & 0.293 & 0.744 & 0.423 & 0.496 \\
\hline $\mathrm{X}_{2.3}$ & 4.050 & 0.598 & 0.911 & 0.464 & 0.668 \\
\hline $\mathrm{X}_{2.4}$ & 4.160 & 0.449 & 0.744 & 0.387 & 0.546 \\
\hline $\mathrm{X}_{2.5}$ & 4.100 & 0.516 & 0.862 & 0.452 & 0.645 \\
\hline $\mathrm{X}_{2.6}$ & 4.180 & 0.371 & 0.731 & 0.420 & 0.321 \\
\hline $\mathrm{X}_{2.7}$ & 4.000 & 0.277 & 0.740 & 0.348 & 0.469 \\
\hline $\mathrm{X}_{2.8}$ & 4.180 & 0.342 & 0.535 & 0.356 & 0.234 \\
\hline \multicolumn{6}{|c|}{ Green Purchasing (GPR) } \\
\hline $\mathrm{Z}_{1}$ & 4.410 & 0.508 & 0.464 & 0.785 & 0.448 \\
\hline $\mathrm{Z}_{2}$ & 4.310 & 0.415 & 0.292 & 0.816 & 0.461 \\
\hline $\mathrm{Z}_{3}$ & 4.200 & 0.415 & 0.290 & 0.727 & 0.329 \\
\hline $\mathrm{Z}_{4}$ & 4.150 & 0.351 & 0.377 & 0.745 & 0.470 \\
\hline $\mathrm{Z}_{5}$ & 4.300 & 0.291 & 0.345 & 0.657 & 0.380 \\
\hline \multicolumn{6}{|c|}{ Firm Performance (FPR) } \\
\hline$Y_{1}$ & 4.160 & 0.562 & 0.526 & 0.509 & 0.891 \\
\hline $\mathrm{Y}_{2}$ & 4.330 & 0.556 & 0.618 & 0.504 & 0.884 \\
\hline $\mathrm{Y}_{3}$ & 4.280 & 0.503 & 0.519 & 0.501 & 0.906 \\
\hline $\mathrm{Y}_{4}$ & 3.840 & 0.637 & 0.391 & 0.498 & 0.714 \\
\hline $\mathrm{Y}_{5}$ & 4.150 & 0.596 & 0.397 & 0.433 & 0.851 \\
\hline$Y_{6}$ & 4.128 & 0.508 & 0.521 & 0.430 & 0.912 \\
\hline$Y_{7}$ & 4.330 & 0.557 & 0.587 & 0.506 & 0.867 \\
\hline
\end{tabular}

The reliability analysis result is shown in Table 3. Construct reliability testing looks at composite reliability and Cronbach's alpha value. Construct is considered reliable if it has a value of composite reliability $>0.7$ and Cronbach's alpha value $>0.7$. The result revealed that all constructs have composite reliability, and Cronbach's Alpha value greater than the cut-off value of 0.70 . The value of composite reliability and Cronbach's alpha on variable supplier relationship management is 0.904 and 0.878 , the Top Management commitment is 0.869 and 0.819 , green purchasing 
is 0.863 and 0.802 , and firm performance is 0.953 and 0.942 . Since all variables have a value of composite reliability greater than 0.7 and Cronbach's alpha greater than 0.7 , it can be concluded that all indicators are all considered reliable, and further analysis can proceed.

Table 3. Composite Reliability and Cronbach's Alpha

\begin{tabular}{lcc}
\hline Research Constructs & $\begin{array}{l}\text { Composite } \\
\text { Reliability }\end{array}$ & $\begin{array}{c}\text { Cronbach's } \\
\text { Alpha }\end{array}$ \\
\hline $\begin{array}{l}\text { Supplier } \\
\text { Relationship }\end{array}$ & 0.904 & 0.878 \\
Management & & \\
Top management & 0.869 & 0.819 \\
commitment & 0.863 & 0.802 \\
Green Purchasing & 0.953 & 0.942 \\
Firm Performance & & \\
\hline
\end{tabular}

The hypothesis testing uses the $\mathrm{T}$ statistics values and $\mathrm{p}$-value for assessing the rejection or the acceptance of the hypothesis. This study used a significant level of 5\% which implies that hypothesis is supported for $\mathrm{T}$ statistics value greater than 1.96 or p-value less than 0.05 .

Table 4. Hypothesis Testing Result

\begin{tabular}{lccc}
\hline \multicolumn{1}{c}{ Hypothesis } & $\begin{array}{c}\text { Path } \\
\text { Coefficient }\end{array}$ & $\begin{array}{c}\mathrm{T} \\
\text { Statistic }\end{array}$ & $\begin{array}{c}\mathrm{p}- \\
\text { Value }\end{array}$ \\
\hline $\begin{array}{l}\text { Top management } \\
\text { commitment } \rightarrow\end{array}$ & 0.544 & 4.956 & 0.000 \\
$\begin{array}{l}\text { Supplier relationship } \\
\text { management (H1) }\end{array}$ & & & \\
\hline $\begin{array}{l}\text { Top commitment } \\
\text { management } \rightarrow\end{array}$ & 0.266 & 1.815 & 0.055 \\
$\begin{array}{l}\text { Green purchasing } \\
\text { (H2) }\end{array}$ & & & \\
\hline $\begin{array}{l}\text { Top commitment } \\
\text { management } \rightarrow \text { Firm } \\
\text { performance (H3) }\end{array}$ & 0.281 & 2.161 & 0.025 \\
\hline $\begin{array}{l}\text { Supplier relationship } \\
\text { management } \rightarrow\end{array}$ & 0.391 & 3.110 & 0.012 \\
$\begin{array}{l}\text { Green purchasing } \\
\text { (H4) }\end{array}$ & & & \\
\hline $\begin{array}{l}\text { Supplier relationship } \\
\text { management } \rightarrow \text { Firm } \\
\text { performance (H5) }\end{array}$ & 0.377 & 2.251 & 0.018 \\
\hline $\begin{array}{l}\text { Green purchasing } \rightarrow \\
\begin{array}{l}\text { Firm performance } \\
\text { (H6) }\end{array}\end{array}$ & 0.226 & 2.036 & 0.028 \\
\hline
\end{tabular}

Table 4 demonstrates the hypotheses testing result. Five proposed hypotheses (H1, H3, H4, $\mathrm{H} 5, \mathrm{H} 6)$ are supported since the T statistic value exceeds 1.96 and p-value less than 0.005 , while one hypothesis (H2) was not supported.

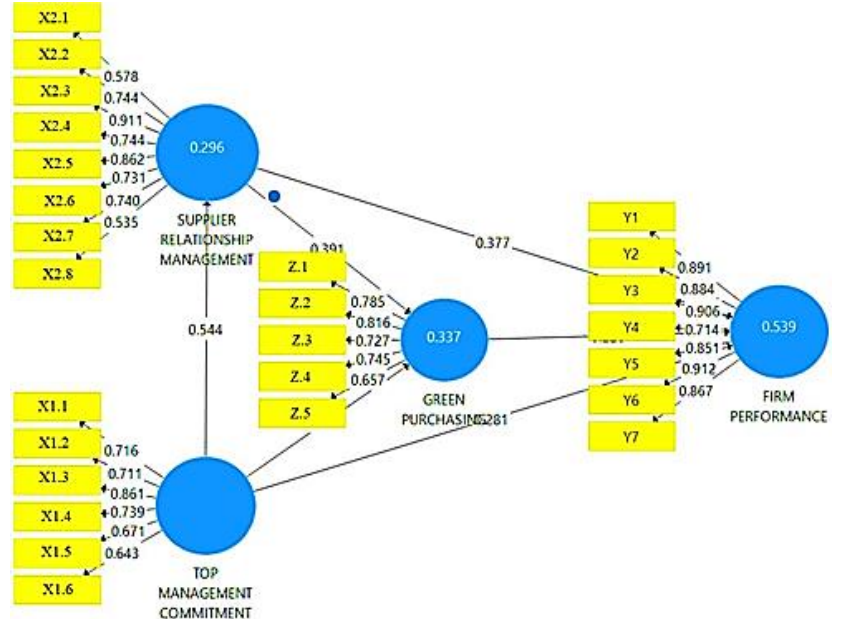

Figure 2. Research Model and Analysis Result

Figure 2 summarizes the research model with the analysis result. The value on the line between construct and indicator represents the factor loading. Besides, the value on the line between constructs indicated the path coefficient, and the value inside the circle showed the $\mathrm{R}^{2}$ values.

\section{Discussion}

As shown in the analysis result (Table 4), H1 is supported, meaning that top commitment management is proven to affect supplier relationship management in 3-star hotels in Surabaya, with a T-statistic value of 4.956> 1.96 and p-value $0.000<0.05$. Furthermore, the influence of top commitment management on supplier relationship management is positive at a path coefficient value of 0.544 . The presence of sound top management commitment such as resources allocation and setting policies in collaboration with supplier will convince the supplier to maintain the long-term relationship. As a result, the supplier will provide their best effort in supporting the company in serving the customer. The results of this study are supported by previous research in that building supplier relationships requires long-term relationships and high commitment (Amoako et al., 2018; Smith et al., 2013).

Unfortunately, the results show that top management commitment did not affect the implementation of green purchasing $(\mathrm{H} 2)$ with a T-statistics value of $1.815<1.96$, p-value of 0.055 $>0.05$, and path coefficient of 0.266 . It appears that top commitment management in terms of 
setting up of policy, resources allocation, and supplier involvement provide no impact of the green purchasing adoption such as minimizing waste through the purchase of products, adherence to environmental regulations in product procurement, or buying product labeled eco-label. This finding is not aligned with a previous study (Menguc et al., 2010), but it is in line with a study by Sundarakani et al. (2010), stating that top management commitment does not affect purchasing strategies in adopting green purchasing in small manufacturing companies in Malaysia.

Furthermore, results demonstrated that top commitment management significantly impacts firm performance (H3) 3-star hotels in Surabaya, with the T-statistic value of 2.161> 1.96 and pvalue of $0.025<0.05$. The influence of top commitment management on firm performance is positive at 0.281 . The stronger the top management commitment, the more significantly improve the firm performance in 3-star hotels in Surabaya. Top management commitment such as allocation of resources required, training of employees enables the company to enhance firm performance in terms of growing market share, saving more expenses, and meeting customer demand on time. This result is in line with previous research (Mokhtar \& Yusof, 2010; Anne et al.,2016; Siagian et al.,2020; Semuel et al., 2017; Tarigan et al., 2021; Jade et al., 2021).

Moreover, the results showed that $\mathrm{H} 4$ is accepted, meaning that supplier relationship management is proven to influence green purchasing at 3-star hotels in Surabaya, with a Tstatistic value of $3.110>1.96$ and p-value of 0.012 $<0.05$. The influence of supplier relationship management on green purchasing was positive at 0.391 . This result means that better supplier relationship management will significantly increase green purchasing at 3-star hotels in Surabaya. These results indicate that the relationship between hotels and suppliers is getting better by sharing new ideas that can influence hotels to implement green purchasing by environmentally friendly products that do not violate environmental regulations. This study supports the results that state that supplier relationship management can influence the adoption of green purchasing in the company itself (Tarigan et al., 2020).

Besides, the finding also revealed that supplier relationship management has a significant effect on firm performance (H5) with the Tstatistics value of 2.251>1.96, a p-value of 0.018 $<0.05$, and a path coefficient of 0.377 . Supplier relationship management plays an essential role in supporting the enhanced firm performance. When the suppliers have good credibility in meeting needs, share the idea with the company, work together closely, and communicate effectively, the Hotel will serve its customer much better, increase customer satisfaction, grow sales, and increase profit. This result aligns with the finding from previous studies (Abdallah et al., 2014; Flynn et al., 2010; Lambert et al., 1998; Monari, 2018; Gitau \& Kosgei, 2016; Tseng, 2014).

The last finding indicated that green purchasing significantly affects firm performance (H6) with a T-statistics value of $2.036>1.96$, a pvalue of $0.028<0.05$, and a path coefficient of 0.226 . Green purchasing is proven to influence firm performance in 3-star hotels in Surabaya. The more extended the green purchasing practices by the Hotel, the higher result of the Hotel's performance. Green purchasing adoption selects a supplier with environmentally friendly criteria, collaborates with suppliers to improve environmentally friendly performance, and buys ecolabel products. These activities will enhance the firm's performance in minimizing waste, growing market share, saving on expenses, reducing energy consumption, implementing green hotels, providing services efficiently, and meeting customer demand. This result is supported by previous research (Selvam et al., 2016; Fahimnia et al., 2015; Sarkis, 2012).

This study's findings can be highlighted based on the previous result. The study has developed six hypotheses to be examined. Five (5) hypotheses were supported, while one hypothesis was not supported. Today green issues have become a severe concern of global society. The business entity should take environmental protection to cope with the customer demand, particularly in the 3-star hotel industry. This study has successfully created a model to seek the extent to which green purchasing enhances the firm performance of the 3-star Hotel in Surabaya. The finding of the result revealed that the top management commitment is essential in improving the firm performance. Supplier relationship management also contributes to improving the firm performance. As expected, green purchasing practiced by the 3-star Hotel in Surabaya contributes significantly to improving the firm performance of the 3-star Hotel. Unfortunately, top management commitment did not indicate its significant contribution in enhancing green purchasing. However, it does not mean that green purchasing is not essential for the company. Green purchasing directly improves the 
firm performance, as revealed by this study. The importance of this finding is that the company's top management needs to consider why they did not contribute to affect green purchasing. The top management needs to support the company program, practice an excellent relationship with major suppliers, and adopt green purchasing practices. Today the issue of a green environment is an emerging issue from society, particularly the customer. The result of this research paves the way for the manager of the 3-star Hotel to enhance its performance. The finding of this study also contributes to the current research in supply chain management. For future research, this study suggested involving broader variables such as green distribution, green production, and green logistics to examine a holistic understanding that all partners in the green supply chain management could improve the firm's performance.

\section{Conclusions}

This study is designed to investigate the effect of top management commitment on firm performance through green purchasing and supplier relationship management in the 3-star hotel industry. The top management commitment significantly affects supplier relationship management (H1). This finding is due to the top management's commitment to providing adequate resources that can substantially influence supplier relationship management. However, (H2) is not supported, stating that top management commitment affects green purchasing. Moreover, top management commitment significantly impacts firm performance $(\mathrm{H} 3)$. The result also revealed that supplier relationship management significantly affects green purchasing (H4). Supplier relationship management influences the firm performance (H5). The last finding showed that green purchasing improved the firm performance (H6). This study could provide insight for managers in manufacturing companies on enhancing firm performance in the context of supply chain management.

The managerial implication of this study is evidence that the top management needs to commit to supporting the company program, practicing an excellent relationship with major suppliers, and adopting green purchasing practices. Today the issue of a green environment is an emerging issue from society, particularly the customer. The result of this research paves the way for the manager of the 3-star Hotel to enhance its performance. The finding of this study also contributes to the current research in supply chain management.

However, this work has some limitations, particularly regarding the population and the variable involved. For future research, this study suggested involving broader variables such as green distribution, green production, and green logistics to examine a holistic understanding that all partners in the green supply chain management could improve the firm's performance

\section{References}

Abdullah, D., Hotrawaisaya, C., Norddin, N., Shaharudin, M. R., Soonthornpipit, H., \& Zainoddin, A.I. (2018). The Factors that Influence the Green Purchasing Practices among Suppliers of Electrical Components. AIP Conference Proceedings. doi: 10.1063/ 1.506269

Al-Abdallah, G. M., Abdallah, A. B., \& Hamdan, K. B. (2014). The Impact of Supplier Relationship Management on the Competitive Performance of Manufacturing Firms. International Journal of Business and Management, 9(2), 192-202. doi: 10.5539/ijbm.v9n2p192

Ali, S. S., Bag, S., Dubey, R., \& Venkatesh, V. G. (2013). Green Purchasing is Key to Superior Performance: An Empirical Study. International Journal of Procurement Management, 6 (2), 187-210, doi: 10.1504/IJPM.2013.052469

Amoako-Gyampah, K., Boakye, K. G., Adaku, E., \& Famiyeh, S. (2018). Supplier Relationship Management and Firm Performance in Developing Economies: A Moderated Mediation Analysis of Flexibility Capability and Ownership Structure. International Journal of Production Economics, 208, 160-170. doi.org/ 10.1016/j.ijpe.2018.11.021

Anne, N., Caroline, N., \& Harriet, K. (2016). Top Management Commitment for Successful Small and Medium Enterprises (Smes): A Hoax or A Reality?. European Scientific Journal, 12(4), 259-267. doi: 10.19044/esj. 2016.v12n4p259

Ar, I. M. (2012). The Impact of Green Product Innovation on Firm Performance and Competitive Capability: The Moderating Role of Managerial Environmental Concern. Procedia -Social and Behavioral Sciences, 62, 854-864, doi.org/10.1016/j.sbspro.2012.09. 144

Blome, C., Hollos, D., \& Paulraj, A. (2014). Green Procurement and Green Supplier Development: Antecedents and Effects on Supplier Performance, International Journal of Pro- 
duction Research, 52(1), 32-49. doi: 10.1080/ 00207543.2013.825748

Chan, R. Y. K., He, H., Chan, H. K. \& Wang, W. Y. C. (2012). Environmental Orientation and Corporate Performance: The Mediation Mechanism of Green Supply Chain Management and the Moderating Effect of Competitive Intensity. Industrial Marketing Management, 41(4), 621-630

Chrisostom, A. O., \& Monari, F. (2018). Influence Green Logistics Management on the Performance of Registered Automotive Firms in Kenya. International Journal of Academic Research in Business and Social Sciences, 8 (4), 351-365. doi: 10.6007/IJARBSS/v8-i4/ 4018

Colicchia, C., Melacini, M., \& Perotti, S. (2011). Benchmarking Supply Chain Sustainability: Insights from A Field Study. Benchmarking: An International Journal, 18(5), 705-732. doi: 10.1108/14635771111166839

Diabet, A., Khodaverdi, R., \& Olfat, L. (2013). An Exploration of Green Supply Chain Practices and Performances in an Automotive Industry. International Journal of Advanced Manufacturing Technology, 68 (1-4), doi: 10.1007/s00170-013-4955-4

Fahimnia, B., Tang, C. S., Davarzani, H., \& Sarkis, J. (2015). Quantitative Models for Managing Supply Chain Risks: A Review. European Journal of Operational Research, 247(1), 1-15. doi:10.1016/j.ejor.2015.04.034

Flynn, B. B., Huo, B., \& Zhao, X. (2010). The Impact of Supply Chain Integration on Performance: A Contingency and Configuration Approach. Journal of Operations Management, 28(1), 58-71. doi: 10.1016/j.jom. 2009.06.001

Giovanni, P. D., \& Vinzi, V. E. (2012). Covariance Versus Component-Based Estimations of Performance in Green Supply Chain Management. International Journal of Production Economics, 135(2), 907-916. doi: 10.1016/j.ijpe.2011.11.001

Goh, M., Over, D. V., Souza, R., \& Sundarakani, B. (2010). A Sustainable Green Supply Chain for Globally Integrated Networks. Enterprise Networks and Logistics for Agile Manufacturing, 191-206. doi: 10.1007/978-1-84996 $-244-59$

Jade, Kezia, S., Siagian, H., \& Tarigan, Z. J. H. (2021). The Effect of Transformational Leadership on Firm Performance through ERP Systems and Supply Chain Integration in the Food and Beverage Industry. International
Journal of Business Studies. ijbs.petra.ac.id/ index.php/ijbs/article/view/167/71

Jahanshahi, A. A., Rezaie, M., Nawaser, K., Ranjbar, V., \& Pitamber, B. K. (2012). Analyzing The Effect of Electronic Commerce on Organizational Performance: Evidence from Small and Medium Enterprises. African Journal of Business Management, 6(15), 6486 -6496. doi: 10.5897/AJBM11.1768

Jiputra, J.A., Tarigan, Z.J.H., and Siagian, H. (2020). The Effect of Information Technology on Retailer Satisfaction through Supply Chain Management Practices and RetailerDistributor Relationship in Modern Retailer Surabaya. International Journal of Business Studies, 3(2), 126-134, doi.org/10.9744/ ijbs. 3.2. $126-134$

Junita, N. (2016, 22 April). Hotel Bintang 3 Paling Diburu Turis Indonesia. Bisnis.com. retrieved from: traveling.bisnis.com/read/20160422/ 102/540851/hotel-bintang-3-paling-di-buruturis-indonesia

Kiarie, D. M., \& Mogeni, L. M. (2016). Effect of Green Logistics Practices on Performance of Supply Chains in Multinational Organizations in Kenya. Industrial Engineering Letters, 6(4). Retrieved from: pdfs.semanticscholar.org/ 9c95/de787def6a574795c47f6e73bfbf0cb9e7 45.pdf?_ga $=2.179668071 .212272335 .156476$ 4129-552134062.1564764129.

Kosgei, R. C. \& Gitau, R. (2016). Effect of Supplier Relationship Management on Organizational Performance: A Case Study of Kenya Airways Limited. International Academic Journal of Procurement and Supply Chain Management, 2(2), 134-148. Retrieved from www.iajournals.org/.articles/iajpscm_v2_i2_1 34_148.pdf

Lambert, D. M., \& Schwieterman, M. A. (2012). Supplier Relationship Management as A Macro Business Process. Supply Chain Management 17(3), 337-352. doi: 10.1108/1359854 1211227153

Laosirihongthong, T., Adebanjo, D., \& Tan, K.C. (2013). Green Supply Chain Management Practices and Performance. Industrial Management \& Data Systems, 113(8), 1088-1109, doi: 10.1108/IMDS-04-2013-0164

Lee, K. H., \& Shin, D. (2010). Consumers' Responses to CSR Activities: The Link-Age Between Increased Awareness and Purchase Intention. Public Relations Review, 36(2), 193-195. doi: 10.1007/s10551-010-0716-6

Meehan, J. \& Bryde, J., (2011). Sustainable Procurement Practice. Business Strategy and the 
Environment, 20(2), 94-106. doi.org/10.1002/ bse. 678

Menguc, B., Auh, S., \&Ozanne, L. (2010). The Interactive Effect of Internal and External Factors on A Proactive Environmental Strategy and Its Influence on A Firm's Performance. Journal of Business Ethics, 94, 279298, doi.org/10.1007/s10551-009-0264-0

Mokhtar, S. S. M., \& Yusof, R. Z. (2010). The Influence of Top Management Commitment, Process Quality Management and Quality Design Onnew Product Performance: A Case of Malaysian Manufacturers. Total Quality Management 21(3), 291-300. doi: 10.1080/14 783360903553198

Morrell, J. V., Mullane, D. L., \& WilliamJr, R. I. (2014). Reinvigorating The Mission Statement Through Top Management Commitment. Management Decision, 52(3), 446-459. doi: 10.1108/MD-10-2012-0736

Ndua, S. T., \& Were, S. (2018). Effect of Green Supply Chain Management Practices on Performance of Kenyan Universities. A Case of University of Nairobi. The Strategic Journal of Business \& Change Management, 5(2), 553-574. Retrieved pdfs.semanticscholar.org/ 0498/3afef3a207634c7ea56d2f40655657181d 77.pdf

Perotti, S., Zorzini, M., Cagno, E. \& Micheli, G.J.L. (2012). Green Supply Chain Practices and Company Performance: The Case of $3 \mathrm{pls}$ in Italy. International Journal of Physical Distribution \& Logistics Management, 42(7), 640-672. doi.org/10.1108/09600031211258138

Sarkis, J. (2012). A Boundaries and Flows Perspective of Green Supply Chain Management. Supply Chain Management: An International Journal, 17, 202-216. doi: 10.1108/ 13598541211212924

Sekaran, U., \& Bougie, R. (2016). Research Methods for Business: A Skill Building Approach. United Kingdom: John Wiley \& Sons

Selvam, M., Gayathri, J., Vasanth, V., Lingaraja, K., \& Marxiaoli, O. S. (2016). Determinants of Firm Performance: A Subjective Model. International Journal of Social Science Studies, 4(7), 90-100. doi: 10.11114/ijsss.v4i7 .1662

Semuel, H., Siagian, H., \& Octavia, S. (2017). The Effect of Leadership and Innovation on Differentiation Strategy and Company Performance. Procedia - Social and Behavioral Sciences, 237, 1152-1159. doi.org/10.1016/ J.SBSPRO.2017.02.171

Siagian, H., Jade, K., \& Tarigan, Z. J. H. (2020). The Role of Affective Leadership in
Improving Firm Performance through The Integrated Internal System and External Integration FMCG Industry. International Journal of Data and Network Science, 4(4), 365-372. doi.org/10.5267/j.ijdns.2020.9.002

Siagian, H., Tarigan, Z. J. H., \& Andreani, F. (2019). The Influence of Information Integration on Hotel Performance Through The Green Operation and Strategic Purchasing. WCSE Summer 2019, 26-31, www.wcse.org/ WCSE_2019_SUMMER/W05.pdf

Smith, A.D., and Rupp, W.T. (2013). Supply Supplier Integration, Procurement, and Outsourcing: Case Study of SCM Social Capital Benefits. International Journal of Logistics Systems and Management, 14(2), 221-241. doi: 10.1504/IJL SM.2013.051340

Sundarakani, B., Souza, R., Goh, M., Over, D.V., Manikandan, S., and Koh, S.C.L. (2010). A Sustainable Green Supply Chain for Globally Integrated Networks. In: Wang L., Koh S. (eds) Enterprise Networks and Logistics for Agile Manufacturing, springer, 191-206.

S. Y. Yen \& Y. X. Yen. (2012). Top Management's Role In Adopting Green Purchasing Standards in High-Tech Industrial Firms. Journal of Business Research, 65(7), 951-959. doi: 10.1016/j.jbusres.2011.05.002.

Tarigan, Z. J. H., Mochtar, J., Basana, S. R., \& Siagian, H. (2021). The Effect of Competency Management on Organizational Performance through Supply Chain Integration and Quality. Uncertain Supply Chain Management, 9(2), 283-294. doi.org/10.5267/j.uscm.2021. 3.004

Tarigan, Z. J. H., \& Siagian, H. (2021). The Effects of Strategic Planning, Purchasing Strategy and Strategic Partnership on Operational Performance. Uncertain Supply Chain Management, 9(2), 363-372. doi.org/10.5267/ j.uscm.2021.2.006

Tarigan, Z.J.H., Siagian, H., Basana, S.R., \& Jie, F. (2019). Effect of Key User Empowerment, Purchasing Strategy, Process Integration, Production System to Operational Performance. E3S Web of Conferences 130, 01042, ICAMME 2018, doi.org/10.1051/e3sconf/20191 3001042

Tarigan, Z.J.H., Siagian, H., \& Jie, F. (2020). The Role of Top Management Commitment to Enhancing the Competitive Advantage through ERP Integration and Purchasing Strategy. International Journal of Enterprise Information Systems, 16(1), 53-68

Teguh, E.D., Devie, and Wijaya, S. (2020). Transformational Leadership in The Hotel Industry: 
A New Look at The Service-Profit-Chain Concept. International Journal of Business Studies, 3(2), 98-109, doi.org/10.9744/ijbs.3. 2.98-109

Tseng, S. M. (2014). The Impact of Knowledge Management Capabilities and Supplier Relationship Management on Corporate Performance. International Journal of Production Economics, 154, 39-47.

Yusliza, M.-Y., Norazmi, N.A., Jabbour, C.J.C., Fernando, Y., Fawehinmi, O. \& Seles, B.M.R.P. (2019). Top Management Commitment, Corporate Social Responsibility and Green Human Resource Management: A Malaysian Study. Benchmarking: An Inter- national Journal, 26(6), 2051-2078. doi.org/ 10.1108/BIJ-09-2018-0283

Zailani, S., Jeyaraman, K., Vengadasan, G., \& Premkumar, R. (2012). Sustainable Supply Chain Management (SSCM) in Malaysia: A Survey. International Journal of Production Economics, 140(1), 330-340, doi.org/10.1016/ j.ijpe.2012.02.008

\section{Acknowledgments}

Authors would like to thank DRPM and Higher Education Indonesia for providing the post graduate grant in funding this research [B/87/E3/RA.00/2020]. 